\title{
A Study of Vocabulary Learning Strategies in EFL Reading of High, Middle and Low Vocabulary Achievers of Thai Tertiary Students
}

Jarinya Srimanee ${ }^{1 *}$, Kritchada Ruangnoi ${ }^{2}$ \& Mohamad Jafre Bin Zainol Abidin ${ }^{3}$

'Lecturer of English, College of Industrial Technology and Management, Rajamangala University of Technology Srivijaya, Thailand

${ }^{2}$ Ph.D. Student, University of Sains Malaysia

${ }^{3}$ Associate Professor. Ph.D., School of Educational Studies, University of Sains Malaysia

Corresponding Author: Jarinya Srimanee, E-mail: jsrimanee@gmail.com

\section{ARTICLE INFORMATION ABSTRACT}

Received: December 17, 2020

Accepted: February 18, 2021

Volume: 4

Issue: 2

DOI: 10.32996/ijllt.2021.4.2.5

\section{KEYWORDS}

Vocabulary Learning Strategy

(VLS), EFL, Vocabulary Acquisition

(VA) Reading

Comprehension
This research investigated vocabulary acquisition (VA) and vocabulary learning strategies (VLS) use of Thai EFL graduates of a government university in southern Thailand through English narrative readings that inserted fifteen target words into each reading text. The main purpose of the reading treatment was reading comprehension skills. The study also examined implications for EFL vocabulary learning and teaching in Thai context. The sample of fifteen Thai EFL graduates was selected from one group of 40 first year students majoring in Accountancy from a southern Thailand government university. Data were collected using a semistructured interview. The interview session was used to elicit information about their VLS use and vocabulary learning experiences. The interview forms after the reading treatment provided a greater insight into the interviewing process behind the participants' VLS selection and showed how they deduced word meanings of unfamiliar English vocabulary in the narrative reading tasks. Research findings showed that Thai EFL learners in this study apparently show a greater preference for the translation, metacognitive regulation, memory and cognitive strategies than for the determination, metacognitive and social strategies. The findings demonstrate the indirect influence of learners' previous English vocabulary learning on their English language skill development. In addition, this study suggests a close link between vocabulary learning strategy selection, vocabulary knowledge and language skill development in EFL context, especially southern Thailand.

\section{Introduction}

Vocabulary knowledge has been identified as an important element for language learning due to poor understanding of vocabulary causes learners to face language learning difficulties. Inadequate vocabulary repertoires may contribute to several problems of understanding for EFL/ ESL learners who might encounter difficulties in adopting techniques for reading, such as concentrating on the text message and guessing unfamiliar lexical objects (Sim \& Laufer-Dvorkin, 1984).

Vocabulary Learning Strategies (VLS) study has demonstrated that learners' usage of vocabulary learning strategies can have an effect on vocabulary learning to a degree (Schmitt, 1997; Folse, 2004). It is understood that vocabulary learning (VA) and reading happen at the same moment. In the reading phase, beginning readers can come across several new terms. Learners ought to implement lexical decoding methods as applied to new phrases in order to decode the texts (Fraser, 1999). By reading, EFL learners can also gain vocabulary and introducing learners to understandable input marginally above their current stage can contribute to effective learning of language (Krashen, 1989; 2004). Problems with the interpretation of students may, however, emerge from a lack of context information, inability to refer to the document, poor knowledge of vocabulary, or lack of fluency (Tompkins, 2010). Consequently, supplementing EFL / ESL inexperienced persons with an extensive form of narrative texts introduces them to a large quantity of content past their linguistic expertise (Grabe \& Stoller, 2002), which is satisfying at the same time. In fact, when learners do a reading exercise, they determine how they gain new vocabulary after decoding text. Using

K C AL-KINDI CENTER R D FOR RESEARCH AN Your gateway to world-class research

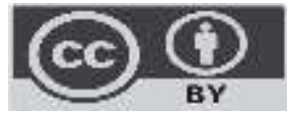

Published by Al-Kindi Center for Research and Development. Copyright (c) the author(s). This open access article is distributed under a Creative Commons Attribution (CC-BY) 4.0 license 
dictionary look-up behavior and translation, as well as techniques related to material forecasting, guessing word meanings from contextual cues, mixing facts, using simple background knowledge, and translating general reading content, are involved as a reader tries to make sense of a document reading. To assume or check for their concepts, the reader must use these approaches if no word meanings exist in the text (Rott, 2007).

There are three main reasons which have prompted this research study:

a. There are not many academic studies that investigate vocabulary learning at a technical college in Thailand by reading and the VLS usage of young adult Thai ESL learners. The current study could fill this void in the development of vocabulary by utilizing testing technique for reading and vocabulary learning.

b. To provide a platform to a community of Thai EFL learners from other big fields to communicate their English vocabulary learning concerns, rather than English major, and to show their critical usage of vocabulary learning in a reading assignment. Research studies (Gu 2003; Country, 2001; Schmitt, 2004) have shown that learners vary in their range and use of VLS; it is therefore important to educate teachers about the needs for vocabulary learning and the usage of VLS in this target community.

c. To draw the attention of language educators to the need for explicit vocabulary teaching and VLS instruction not only in Thailand but also in EFL language institutes in countries where EFL students intend to study in a university environment.

Therefore, the present study aims to investigate the prevalence of VLS use of Thai EFL students in high, middle and low proficiency groups in a reading class. The results of this research are expected to apply to other EFL students. It is essential and useful for both language teachers and learners because the findings will highlight the use of VLS, and conceptions and misconceptions of vocabulary learning as well as reflect upon the beliefs or thinking regarding strategies for learning and acquiring vocabulary items.

The study was limited to first-year EFL Thai students in a government college of industrial technology and management in the southern region, where the situation and context might differ from those in different age groups, proficiency levels, and locations. This study examined the 15 participants' uses of VLS through five short narrative readings. No other non-relevant vocabulary was tested. Furthermore, the semi-structured focused only on 6 questions throughout the reading treatment. There were only 5 students in each proficiency group of vocabulary acquisition involved in this study. The subjects of the study constituted a small group of students. Therefore, the findings should be taken as tentative rather than conclusive.

\section{Background of the Study}

Thai students are expected to learn English from grades 1 to 12 in the Thai school system, an English program under the National Education Act of 2008 (Ministry of Education, 2008). University students need to take at least four courses of English at tertiary level, for instance, two general courses and two courses of English for academic (EAP) or special reasons (ESP) (Ministry of Education, 2008). In the frequent usage of the English language both within and beyond the environments of the school, students also experience learning difficulties, and they normally see unfamiliar terms as the first challenge to be solved. This may be because vocabulary has been accepted as essential to the usage of languages in which learners' poor vocabulary awareness has contributed to second language learning problems (Asgari \& Mustapha, 2011).

Srisawat and Poonpon (2014) revealed that Thai students did not fulfill the language criteria (2,000-3,000 words) and did not hit any word standard. To understand a letter, they discovered that making a broad word size was important. Supatranont (2005) observed that at 1000 Words Class, 2000 Words Level and Academic Words Level, Thai students at Rajamangala University of Technology Lanna (RMUTL) had vocabulary sizes of only $56 \%, 24 \%$ and $18 \%$. Nation (1990) Vocabulary Level Exam was used in the study. Results revealed that 2000-3,000 word size is required to interpret a letter.

One of the most complicated issues of ineffective learning of English vocabulary in the reading process in Thailand is that students neglect basic awareness of vocabulary, which can affect the interpretation of reading by students (Sripetpun, 2000; Songsangkaew, 2003).

Therefore, the current study sheds light on the process by examining the strategies that learners use to develop vocabulary as they access the reading treatment to their regular classes. Adequate exposure to vocabulary considers one of essential feature in acquiring lexical knowledge. Thus, reading lessons were supplemented with exposure to new words within the readers' level of English proficiency.

It is important to be aware of these crucial issues and the fundamentals of vocabulary learning techniques, as well as how students with various types of English proficiency employ prevalence VLSs. That is to say, the study examined more insight into 
how Thai learners view the use of vocabulary learning strategies through their reading exposure to acquire new vocabulary in the reading class.

\section{Purpose of the Study}

The purpose of this study is to find out the high, middle and low achievers experience on vocabulary acquisition and VLS through the reading treatment. Therefore, the research question is "What do the high, middle and low achievers experience in acquiring the target words in the reading treatment?"

\section{Research Methodology}

To find out the increase and improvement of the participants' vocabulary knowledge through the use of VLS in short narrative readings, pre- and post- tests vocabulary gain tests were administered to 40 students. On average, the students were at a moderate English proficiency level according to their results from a university placement test in the academic year 2018. Their mean scores on English were 52.50\%. In addition, their English mean scores on the final test (semester 1, 2018) administered by the English department of the university was $68.94 \%$.

After analysing the post-tests, the 40 participants were selected based on their post-tests' scores and voluntary basis. As a result, there were five high, five middle and five low achieving students according to their ranks in each category of proficiency groups (five highest achievers, five middle achievers and five lowest achievers). The study aims to investigate the VSL employed by the high, middle and low proficient students because the researcher would like to later utilize the findings from the study and apply them in practical terms, such as teaching other different campus or/and levels of English proficiency of the students to enhance and develop their vocabulary knowledge and skills.

The process of selecting suitable participants in the interview session, building a good rapport with the 15 participants, conducting interviews with each participant, translating and transcribing the audio recording of the participants' interview responses and their oral discussion from Thai to English would require a greater commitment of time than the time required to conduct a questionnaire survey with a large group.

The questions on the interview were primarily related to the significance and difficulty of English vocabulary learning and VLS, participants' use of vocabulary learning strategies and their perspectives about vocabulary knowledge. Open-ended questions as presented in the interview were raised during the interviews so as to enable the interviewees to present and explain their ideas in more detail. In other words, the questions were raised to elicit but not to restrict the interviewees' responses. Before implementing interviews, the consent forms written in Thai were distributed to the participants and they signed the form on a voluntary basis.

The semi-structured interview questions focus on the following issues:
a. difficulties faced when reading English texts
b. importance of vocabulary learning
c. English vocabulary-learning difficulties
d. effectiveness of their vocabulary learning strategies
e. recommendation for more effective vocabulary learning in the classroom

During the interview session, the list of fifteen target words was presented to each interviewee. The interviewees were asked to explain the reasons how and why they have employed in the reading process in order to unlock and comprehend each target word's meaning. The interviews were conducted in their L1 (Thai) to avoid misunderstanding of any directions and the interview form will be also prepared in Thai to assist the researcher in eliciting more detailed responses from the interviewees. The interview sessions were approximately 20 minutes per interviewee. The main purpose of the interview was to elicit information to gain a deeper understanding of their English language learning difficulties especially in terms of vocabulary-learning, their strategies to overcome them and their strategies to learn the meaning of English words encountered in different contexts. Information elicited from the different perspectives could help to provide a better overview of participants' vocabulary learning behavior and their VLS use. The six interview questions are as follows:

a. How do you find short narrative reading for vocabulary learning?

b. Do you have any problems with new vocabulary acquisition in reading? If so, what is your problem? Please discuss."

c. Do you use any strategies/techniques that help you deal with vocabulary learning? If so, what methods do you use?

d. Do you use any strategies/techniques that help you deal with vocabulary learning? If so, what methods do you use?" 
e. What do you think about knowing words in the reading materials, such as its collocations, various meanings, and how to use the word?

f. Do you think it is important to know both a basic word meaning and its depth meaning?

The data obtained from the interview was analysed by categorising and further quantified using frequencies and percentages to provide support evidences related to the students' VLS use. Generally, the data was given additional insight into a phenomenon, complement quantitative data and help strengthen validity.

All the interviews were firstly transcribed in Thai before they were carefully translated into English. The translation of the interviews was later reviewed and checked by an experienced EFL lecturer in linguistics who is native in Thai and fluent in English, so as to guarantee the accuracy and reliability of the translation. No serious inconsistencies regarding the translation of the interviews were found between, except for some suggestions on improving a few English expressions, such as tense coherence.

The qualitative and quantitative data from the interview session was combined and quantified to calculate the mean values of the most frequent strategies the five high, five middle, and five low achievers used. In order to determine which strategies, the interviewees used in acquiring words through narrative readings, the mean values were used to determine the most frequently used type of VLS employed overall by the participants as well as the frequency.

Regarding a phenomenographic analysis, in which key data were coded into categories (e.g., 'types of VLS', frequency of use), then depending on the frequency of the 'codes', grouped in themes. The interview data was analysed quantitatively by putting the themes in a table in categories and counting them. Excerpts from the interview show how high, middle and low achievers responded to the questions.

\section{Research Findings}

This session reports the result from the semi-structured interview from 15 students; 5 students from high achieving group, 5 students from middle achieving group and 5 students from low achieving group. The interview data clearly demonstrated that, first of all, most interviewees considered English vocabulary quite important for the reading tasks especially for the reading comprehension process, whereas only one low achieving interviewee questioned the importance of learning English vocabulary since he thought that a certain amount of vocabulary would be enough for passing the English test.

Secondly, regardless of their proficiency levels, a predominant number of interviewees encountered various difficulties in learning English vocabulary, for example, it was hard to remember new English words for a long time; they had no efficient methods to remember new English words; it was hard to remember the long words, the words with irregular spellings and the infrequent words. The low achieving students had more difficulties in learning English vocabulary than did both high and middle achieving students, especially in maintaining the long-term memory of learnt words, and lacking of efficient methods to remember new words. In addition, the low and middle achieving students confronted more problems relating to the learning of vocabulary depth than did the high achieving students

Thirdly, the participants reported using self-initiated strategies, using dictionary, inferencing, note-taking, social, association strategies, repetition and using context to. remember new English words. Among these strategies, self-initiated strategies, using dictionary, inferencing, and repetition were more frequently mentioned by these participants, whereas, note-taking, social, and association strategies were less frequently reported by them. In addition, the high achieving students reported using a wider range of VLSs than did both intermediate and low achieving students; especially they mentioned more self-initiated strategies, dictionary strategies, and inferencing strategies. By contrast, the middle and low achieving students reported more repetition strategies than did the high achieving students. The low achieving group did not mention using any inferencing strategy.

Fourthly, when discussing the useful strategies for enlarging vocabulary size or improving the depth of vocabulary knowledge, the high achieving students mentioned more strategies than did both middle and low achieving students. However, despite their proficiency levels, they all reported fewer useful strategies for improving the depth of vocabulary knowledge than those suggested for enlarging vocabulary size.

Fifthly, as for the participants' knowledge sources of strategy use, they reported three aspects: strategies explored by themselves, those introduced by their English lecturers and those introduced by others (e.g., relatives, classmates). The high achieving students tended to combine their self-initiated strategies with their English lecturers' advice in terms of the use of VLSs. By contrast, most middle and low achieving students mainly relied on advice from their English lecturers or others. 
Sixthly, the participants from the three proficiency levels shared relatively similar perspectives about vocabulary knowledge. Vocabulary size was regarded as quantity, easy to learn, knowing the basic meaning and foundation for English learning, while vocabulary depth was considered as quality, difficult to learn and knowing how to use a word.

Finally, when discussing the importance of vocabulary size/depth, most intermediate and low achieving students regarded vocabulary size as more important than depth, while most high achieving students emphasized the significant role of vocabulary depth. Another two students (one high- and one middle- achieving students) considered both were equally important for them (See Table 1 for a summary of the interview analyses).

\section{Table 1: A Summary of the Interview Analysis}

\begin{tabular}{|c|c|c|c|}
\hline \multirow[t]{2}{*}{ Data Summary } & \multicolumn{3}{|c|}{ Group of Achievers } \\
\hline & High & Middle & Low \\
\hline $\begin{array}{l}\text { 1. Importance of } \\
\text { learning English } \\
\text { Vocabulary }\end{array}$ & Very important & Very important & Very important \\
\hline $\begin{array}{l}\text { 2. Difficulties of learning } \\
\text { English Vocabulary }\end{array}$ & $\begin{array}{l}\text { Hard to remember new } \\
\text { English words for a long } \\
\text { time }\end{array}$ & $\begin{array}{l}\text { Hard to remember new } \\
\text { words for a long time } \\
\text { Having no efficient } \\
\text { methods to remember } \\
\text { new English words }\end{array}$ & $\begin{array}{l}\text { Hard to remember new } \\
\text { words for a long time }\end{array}$ \\
\hline & $\begin{array}{l}\text { Having no efficient } \\
\text { methods to remember } \\
\text { new English words }\end{array}$ & $\begin{array}{l}\text { Difficult to remember } \\
\text { long words, the words } \\
\text { with irregular spellings } \\
\text { and the infrequent words }\end{array}$ & $\begin{array}{l}\text { Having no efficient } \\
\text { methods to remember } \\
\text { new English words }\end{array}$ \\
\hline & $\begin{array}{l}\text { Difficult to remember the } \\
\text { long words, the words } \\
\text { with irregular spellings } \\
\text { and the infrequent words }\end{array}$ & $\begin{array}{l}\text { Hard to learn the depth } \\
\text { of vocabulary knowledge }\end{array}$ & $\begin{array}{l}\text { Hard to learn the depth } \\
\text { of vocabulary knowledge }\end{array}$ \\
\hline & $\begin{array}{l}\text { No problem of } \\
\text { memorizing words }\end{array}$ & $\begin{array}{l}\text { Too many English words } \\
\text { to remember }\end{array}$ & $\begin{array}{l}\text { Some English words you } \\
\text { can recognize, but you } \\
\text { cannot produce them. }\end{array}$ \\
\hline \multirow[t]{8}{*}{ 3. $\mathrm{S}$} & Self-initiated strategies & Self-initiated strategies & Self-initiated strategies \\
\hline & Inferencing strategies & Inferencing strategies & Using dictionary \\
\hline & Using dictionary & Using dictionary & $\begin{array}{l}\text { Using context to } \\
\text { remember new words }\end{array}$ \\
\hline & $\begin{array}{l}\text { Using context to } \\
\text { remember new words }\end{array}$ & $\begin{array}{l}\text { Using context to } \\
\text { remember new words }\end{array}$ & Repetition strategies \\
\hline & Note-taking strategies & Social strategies & Association strategies \\
\hline & Social strategies & Repetition strategies & \\
\hline & Association strategies & & \\
\hline & Repetition strategies & & \\
\hline \multirow{3}{*}{$\begin{array}{l}\text { VLS perceived useful for } \\
\text { enlarging Vocabulary size }\end{array}$} & Self-initiated strategies & Self-initiated strategies & Self-initiated strategies \\
\hline & Inferencing strategies & Inferencing strategies & Using dictionary \\
\hline & Using dictionary & Using dictionary & Using context to \\
\hline
\end{tabular}




$\begin{array}{lll}\text { Note-taking strategies } & \text { Repetition strategies } & \text { remember new words } \\ \text { Using context to } & \text { Using context to } & \\ \text { remember new words } & \text { remember new words }\end{array}$

Association strategies

Table 2: A Summary of the Interview Analysis (Continued)

\begin{tabular}{|c|c|c|c|}
\hline \multirow[t]{2}{*}{ Data Summary } & \multicolumn{3}{|c|}{ Group of Achievers } \\
\hline & High & Middle & Low \\
\hline \multirow{4}{*}{$\begin{array}{l}\text { VLS perceived useful for } \\
\text { improving Vocabulary } \\
\text { depth }\end{array}$} & Self-initiated strategies & Self-initiated strategies & Self-initiated strategies \\
\hline & $\begin{array}{l}\text { Using context to } \\
\text { remember new words }\end{array}$ & Repetition strategies & $\begin{array}{l}\text { Using context to } \\
\text { remember new words }\end{array}$ \\
\hline & Note-taking strategies & & \\
\hline & Using dictionary & & \\
\hline \multirow{3}{*}{$\begin{array}{l}\text { Knowledge sources of } \\
\text { VLS use }\end{array}$} & Explore by themselves & Explore by themselves & Explore by themselves \\
\hline & $\begin{array}{l}\text { Introduce by their English } \\
\text { lecturers }\end{array}$ & $\begin{array}{l}\text { Introduce by their English } \\
\text { lecturers }\end{array}$ & $\begin{array}{l}\text { Introduce by their English } \\
\text { lecturers }\end{array}$ \\
\hline & & $\begin{array}{l}\text { Introduce by others (e.g. } \\
\text { relatives, classmates) }\end{array}$ & \\
\hline \multirow{4}{*}{$\begin{array}{l}\text { Perspective on } \\
\text { Vocabulary size }\end{array}$} & Quantity & Quantity & Quantity \\
\hline & Easy to learn & Easy to learn & Easy to learn \\
\hline & $\begin{array}{l}\text { Knowing the basic } \\
\text { meaning }\end{array}$ & $\begin{array}{l}\text { Knowing the basic } \\
\text { meaning }\end{array}$ & $\begin{array}{l}\text { Knowing the basic } \\
\text { meaning }\end{array}$ \\
\hline & $\begin{array}{l}\text { Foundation for English } \\
\text { learning }\end{array}$ & $\begin{array}{l}\text { Foundation for English } \\
\text { learning }\end{array}$ & \\
\hline \multirow{3}{*}{$\begin{array}{l}\text { Perspective on } \\
\text { Vocabulary Depth }\end{array}$} & Quality & Quality & Quality \\
\hline & Difficult to learn & Difficult to learn & Difficult to learn \\
\hline & $\begin{array}{l}\text { Knowing how to use a } \\
\text { word }\end{array}$ & & $\begin{array}{l}\text { Knowing how to use a } \\
\text { word }\end{array}$ \\
\hline \multirow{3}{*}{$\begin{array}{l}\text { Perspective on the } \\
\text { importance of vocabulary } \\
\text { size and depth }\end{array}$} & Vocabulary size & Vocabulary size & Vocabulary size \\
\hline & Vocabulary depth & Vocabulary depth & \\
\hline & Both & Both & \\
\hline
\end{tabular}

\section{Discussion}

It was unsurprising to find that the participants reported using both oral and written repetition strategies most frequently, as Thai EFL learners are generally believed to be good at using rote memorization. This result may be influenced by the Thai culture and Thai students' L1 learning background. Moreover, Thai EFL students are more likely to use rote memory to learn their L1 as they are encouraged by some Thai lecturers to recite some texts in Thai textbooks and to memorize some exemplar Thai essays. Therefore, they may transfer those learning strategies of their L1 learning when learning an L2. In addition, using dictionaries and inferencing strategies were also frequently reported by the participants and these two kinds of strategies were generally considered as two popular VLSs among Thai EFL students (Gu \& Johnson, 1996). On the contrary, this study found that the participants seldom reported using production-based strategies. This finding was quite understandable as in the Thai EFL 
context; the students have few opportunities to use English in their daily life. In addition, they did not favor association and imagination strategies which may be due to language distance between Thai and English and also their L1 learning background. Nevertheless, it was unexpected to find that note-taking strategies were not frequently reported by these participants.

In comparison with previous studies, the current findings were partially consistent with those reported by Gu and Johnson (1996). Both studies found that EFL learners reported using inferencing strategies and dictionaries most frequently, whereas they reported adopting production-based strategies (activation strategies) and association and imagination strategies (encoding strategies) least frequently. Nevertheless, there were also some differences between the findings of these two studies. In the present study, both oral and written repetitions were the most popular strategies reported by the participants, whereas in Gu and Johnson's (1996) study, the participants were less likely to use written repetition strategies compared to other strategies. Moreover, note-taking strategies were reportedly the least frequently used strategies by the participants in the present study, however, in Gu and Johnson's (1996) study, note-taking strategies ranked the third most frequently used strategies. In addition, the results of the present study endorsed the findings presented in other relevant studies on EFL learning. For instance, Catalán (2003), Kojic-Sabo and Lightbown (1999), Riazi and Alvari (2004), and Schmitt (1997) found that EFL learners tended to make use of dictionaries, inferencing strategies, note-taking and repetition strategies, and used less mnemonic and association strategies. Nevertheless, one difference between the findings of the present study and those of the above studies was that the participants in the present study infrequently reported using note-taking strategies when learning English vocabulary.

In the ESL learning context, Fan (2003) found that inferencing strategies were most frequently used by the Chinese ESL university students in Hong Kong, indicating that inferencing strategies were favored by both Chinese EFL and ESL university students. Fan (2003) also found that Hong Kong students did not favor association strategies, which resembled the finding of the present study. However, the difference between the findings of these two studies was that ESL university students in Fan's (2003) study tended to use more strategies for consolidating known words, such as revising newly learnt words, while they used less repetition strategies in comparison to the EFL university students of the present study.

The above discussion suggests that, similar to the results of the other relevant EFL studies, the participants of the present study reported using repetition strategies, inferencing strategies, and dictionaries most frequently, while disfavored production-based strategies and association and imagination strategies. Nevertheless, the only difference noted between this and other studies was in the use of note-taking strategies, which was less favorable in the present study compared to other relevant EFL vocabulary studies. In comparison to Fan's (2003) study, both ESL and EFL students favored inferencing strategies whereas disfavored association strategies. However, the EFL university students adopted more strategies for consolidating known words, while they used fewer repetition strategies than did the Thai EFL students of the present study.

\section{Conclusion}

The results of the study showed that the participants reported favoring repetition strategies, inferencing strategies and using dictionaries, but reported disfavoring note-taking strategies, production-based strategies and association and imagination strategies. The high achieving students reported using more VLSs than did both middle and low achieving students, in particular, they reported more inferencing strategies. In addition, the high achieving students tended to combine self-initiated strategies, dictionary strategies, and inferencing strategies in vocabulary learning. Moreover, as for the participants' knowledge sources of strategy use, the high achieving students combined their self-initiated strategies with their English teachers' advice. By contrast, most middle and low proficiency students mainly relied on advice from their English lecturers or others.

\section{Recommendations for Further Research}

The present results were based on the students' recall of vocabulary learning experience in their reading treatment. These selfreport data may not be consistent with reality in other circumstances. In order to achieve more reliable findings, future research may be beneficial in using ethnographic methods to observe the use of VLSs by EFL learners.

\section{References}

[1] Asgari, A., \& Mustapha, A. B. (2011). The type of vocabulary learning strategies used by ESL students in University Putra Malaysia. English Language Teaching, 4(2), 84-90.

[2] Catalán, R. M. J. (2003). Sex differences in L2 vocabulary learning strategies. International Journal of Applied Linguistics, $13(1), 54-77$.

[3] Fan, M. (2003). Frequency of Use, Perceived Usefulness and Actual Usefulness of Second Language Vocabulary Strategies: A study of Hong Kong learners. The Modern Language Journal, 87(2), 222-241.

[4] Folse, K. S. (2004). Vocabulary myths: Applying second language research to classroom teaching. The University of Michigan Press.

[5] Grabe, W., \& Stoller, F. (2002). Teaching and researching reading. Harlow: Pearson Education. 
[6] Gu, P. Y. (2003). Vocabulary Learning in a Second Language: Person, Task, Context and Strategies. Teaching English as a Second or Foreign Language TESL-EJ,. 7(2), 1-11.

[7] Gu, Y., \& Johnson, R. K. (1996). Vocabulary learning strategies and language learning outcomes. Language learning, 46(4), 643-679.

[8] Kojic-Sabo, I. \& Lightbown, P. M. (1999). Students' approaches to vocabulary learning and their relationship to success. The Modern Language Journal, 83, 177-191.

[9] Krashen, S. (1989). We acquire vocabulary and spelling by reading: additional evidence for the input hypothesis. The Modern Language Journal, 73(4), 440-464.

[10] Krashen, S. (2004). The power of reading: Insights from the research (2 $2^{\text {nd }}$ ed.) Englewood, CA: Libraries Unlimited.

[11] Ministry of Education (MOE). (2008). Basic Education Curriculum B. E. 2551(A.D. 2001). Bangkok, Thailand: Ministry of Education.

[12] Nation, P. (1990). Teaching \& learning vocabulary. Rowley, MA: Newbury House.

[13] Riazi, A., \& Alvari, A. (2004). Strategy activation in learning English words. Academic Exchange Quarterly, 8(2), 199-204.

[14] Rott, S. (2007). The effect of frequency of input enhancements on word learning and text comprehension. Language Learning, 57(2), 165199.

[15] Schmitt, N. (1997). Vocabulary Learning Strategies. In Schmitt, N., and McCarthy, M. (Eds.). Vocabulary: Description, Acquisition and Pedagogy. Cambridge: Cambridge University Press.

[16] Sim, D. D., \& Laufer-Dvorkin, B. (1984). Vocabulary Development. London: Collins English Language Teaching.

[17] Songsangkaew, P. (2003). The language function difficulties experienced by Thai students in real situations in America, [Unpublished master's thesis]. King Mongkut's Institute of Technology North Bangkok, BKK, Thailand.

[18] Sripetpun, W. (2000). The influence of vocabulary size on vocabulary learning strategies and vocabulary learning strategies [Unpublished Doctoral Dissertation]. Victoria: La Trobe University, Australia.

[19] Srisawat, C., \& Poonpon, K. (2014). An Investigation of vocabulary size of Thai university students. In The 3rd International Conference "Language, Society, and Culture in Asian Contexts"(LSCAC 2014) on Asian Dynamics: Prospects and Challenge.

[20] Supatranont, P. (2005). A comparison of the effects of the concordance-based and the conventional teaching methods on engineering students' English vocabulary learning [Doctoral Dissertation]. Chulalondkorn University.

[21] Tompkins, G. E. (2010). Literacy for the 21st century: A balanced approach (5th ed.). Boston: Pearson Education Inc. 